\title{
Physiological role of seminal components in the reproductive tract of the female pig
}

\author{
R. Claus \\ Universität Hohenheim, Institut für Tierhaltung und Tierzüchtung-470, P.O.B. 700562 , \\ 7000 Stuttgart 70, West Germany
}

\begin{abstract}
Summary. In many species the appearance of oestrus is sufficient to ensure that the time of ejaculation, sperm transport and capacitation are balanced with the time of ovulation. In the pig these phenomena vary considerably and require additional regulatory mechanisms which are partly explained by seminal components.

Boar semen is rich in oestrogens (up to $11.5 \mu \mathrm{g} /$ ejaculate). Infusion of saline with the addition of oestrogens in physiological amounts increased the myometrial contraction frequency up to $2 \cdot 5$-fold. This effect is explained by a release of PGF- $2 \alpha$ immediately after oestrogen infusion. Such an infusion also raises peripheral oestrogen concentrations and an effect on LH release can be demonstrated. Additionally, PGF$2 \alpha$ is measurable in uterine vein plasma after oestrogen infusion and is transferred into the follicular fluid. The effect of oestrogens on LH and follicular PGF-2 $\alpha$ is likely to contribute to the timing of ovulation in response to mating.

A specific protein of $M_{r} 100000-110000$ has been detected in boar seminal plasma and it exerts a strong immunosuppressive effect. This protein may be involved in a protection of spermatozoa but also of early embryos against female immunological attack. The addition of such specific compounds to AI doses, in which seminal plasma is diluted, may improve prolificacy.
\end{abstract}

Keywords: semen; oestrogens; myometrium; ovulation; immunosuppression; prostaglandins; pig

\section{Regulatory mechanisms which ensure fertilization}

The pig is a polytocous spontaneous ovulator. The occurrence of the standing reflex is regarded as the main mechanism to time the cascade of physiological events leading to fertilization. The phenomena involved, however, vary considerably in their time relationships and point to a need for additional regulatory mechanisms.

After ejaculation of high volumes into the uterus, spermatozoa are transported to the oviduct by contractions of the myometrium. At 15 min post coitum the uterus is still full of semen (Hunter, 1982), but most of the seminal plasma is resorbed by about $2 \mathrm{~h}$ later (Hunter, 1973) or lost due to cervical backflow (Einarsson \& Viring, 1973). Also most of the spermatozoa have disappeared and the remaining spermatozoa in the uterus loose motility (First et al., 1968a, b). Viable spermatozoa first appear in the oviduct as early as $15-30 \mathrm{~min}$ after artificial insemination (Al) (First et al., 1968a). Thereafter a fairly constant number of spermatozoa is maintained in the utero-tubal junction and the lower part of the isthmus for about 6-24 h. Within the following 2 days spermatozoa disappear gradually (see First et al., 1968a; Polge, 1978; Viring \& Einarsson, 1981). A rapid transport through the uterus and the storage in the upper part of the genital tract seem to be necessary to protect spermatozoa against immunological attack, e.g. by a post-coital invasion of polymorphonuclear leucocytes into the uterine lumen (Lovell \& Getty, 1968; Hunter, 1984). These leucocytes apparently do not enter the isthmus (Fléchon \& Hunter, 1981). 
Capacitation of spermatozoa, which takes several hours (Hunter \& Dziuk, 1968; Imai et al., 1979), does not depend on the uterine milieu and may also occur in the oviduct. As capacitated spermatozoa are unstable cells (Bedford, 1970; Chang \& Hunter, 1975) and ovulation may be delayed, the isthmus seems to have a protective role by arresting capacitated spermatozoa and redistributing them during the periovulatory period. It was suggested that constituents of boar seminal plasma support these mechanisms by modifying the contractile activity of the caudal isthmus (Hunter, 1984).

Ovulation in the pig may occur $40-42 \mathrm{~h}$ after onset of behavioural oestrus (Hunter, 1984). This interval, however, is highly variable, e.g. the interval from onset of standing heat until a rise of progesterone above $1 \mathrm{ng} / \mathrm{ml}$ plasma (demonstrating luteinization as a consequence of ovulation) was $42 \pm 19.9 \mathrm{~h}$ (mean \pm s.d., $\mathrm{N}=25$ ) (unpublished observations). Similarly, maximal concentrations of the preovulatory LH surge may coincide with the onset of behavioural oestrus. In about $20-30 \%$ of sows, however, the LH peak occurs as early as 1 day before or as late as 1 day after the onset of the standing reflex (van de Wiel et al., 1981; Foxcroft \& van de Wiel 1982; Guthrie $e t$ al., 1972; Tilton et al., 1982). Also a high variability was demonstrated (see Fig. 1) for the LH surge in relation to the drop of oestradiol concentrations (signalling ovulation) and additionally the increase of progesterone concentrations.

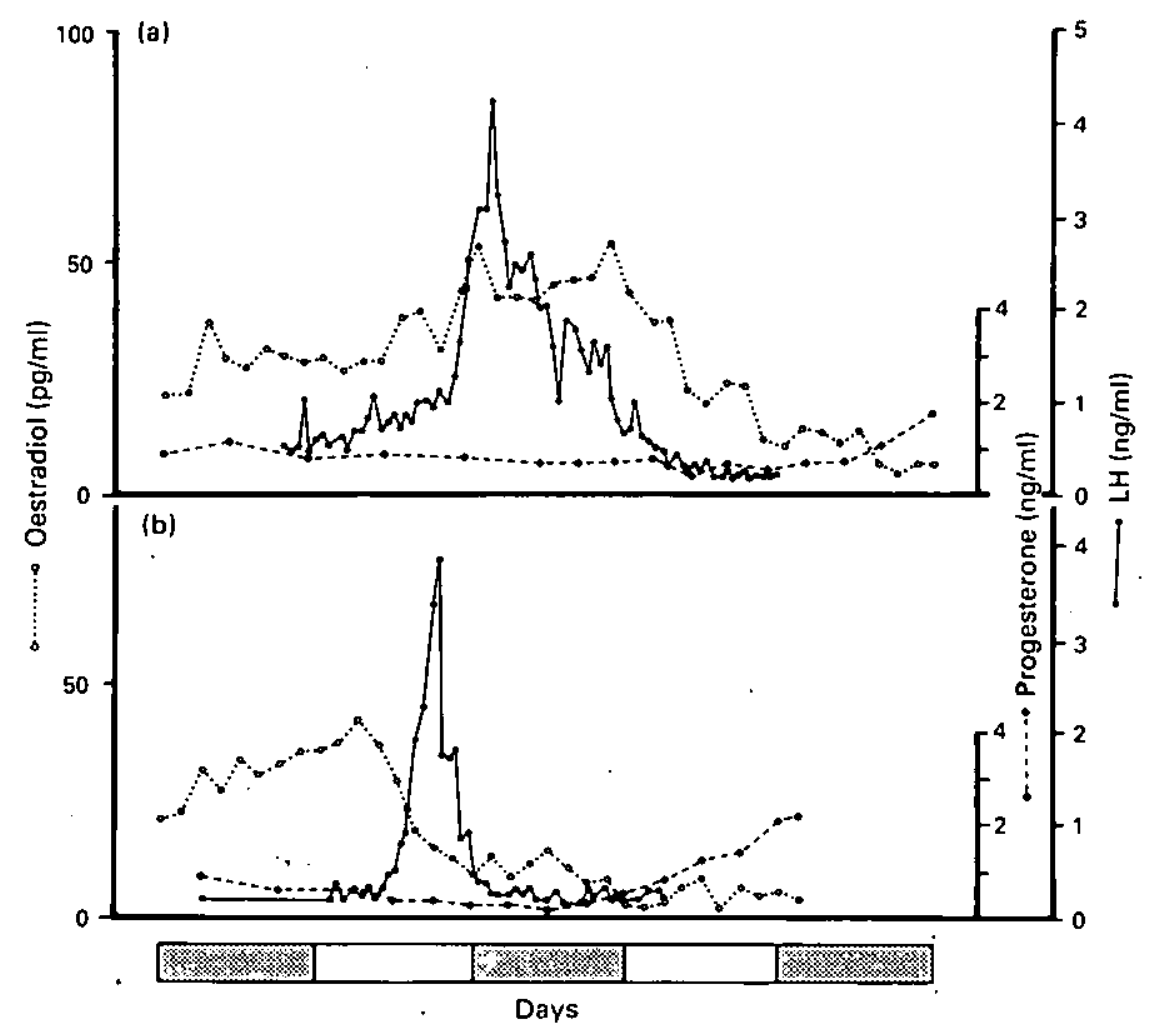

Fig. 1. Profiles of oestradiol-17ß, LH and progesterone in two sows kept without boar contact. The LH maximum either occurred $19 \mathrm{~h}$ before the oestradiol maximum (a) or $12 \mathrm{~h}$ after the maximum (b), but an increase of progesterone above $1 \mathrm{ng} / \mathrm{ml}$ in relation to the oestradiol maximum followed similarly after $43 \mathrm{~h}$ or $49 \mathrm{~h}$ (R. Claus, C. Hoang-Vu \& U. Weiler, unpublished observations). 
Natural mating compared with $\mathrm{Al}$ in the pig leads to higher conception rates and increased litter sizes, probably due to a higher fertilization rate (Skjervold, 1975; Brandt \& Glodek, 1984). This difference cannot be explained by the volume and sperm number used for AI (Baker et al., 1968) and points to additional regulating stimuli provided by the boar. There is evidence that seminal plasma constituents are involved.

\section{Hormones in semen with effects on female reproductive functions}

Hormones in semen with an oxytocic effect have been measured in several species including the boar. Seminal prostaglandins (PGF-2 $\alpha$ and PGE-2) may reach total amounts of several micrograms per ejaculate in men and rabbits (Mann \& Lutwak-Mann, 1981), but average concentrations in boar semen are $<0.5 \mathrm{ng} / \mathrm{ml}$ for both prostaglandins (Hunter, 1973, 1982; Hashizume, 1984). Also, oxytocin concentrations in boar semen were below the assay sensitivity $(1.5 \mathrm{pg} / \mathrm{ml}$; SanderRichter, 1986). Thus, even with regard to the high volume of boar ejaculates, total amounts of these hormones are unlikely to exert physiological effects in the female genital tract.

\section{Seminal oestrogens: a peculiarity of the boar}

Testicular steroids, such as testosterone, $5 \alpha$-dihydrotestosterone, $5 \alpha$-androstenone and conjugated and unconjugated oestrogens which are measurable in the blood plasma of the boar, also occur in semen. Although the concentrations of the C-19 steroids in seminal plasma are only $10 \%$ of those in blood plasma, concentrations of conjugated and unconjugated oestrogens are about $300 \%$ in seminal plasma compared to blood plasma (Claus et al., 1983, 1985). As found in human semen (Allag et al., 1983), oestrogens in the boar are unspecifically bound to the sperm surface, and so oestrogen concentrations in whole semen are about 2-fold compared to seminal plasma (Claus et al., 1985). It is likely that spermatozoa act as a carrier protein because the major part of the oestrogens originates from the seminiferous tubules and accessory glands contribute only about $15 \%$ of the seminal oestrogens as shown by vasectomy (Claus et al., 1985). In semen conjugated oestrogens are mainly represented by oestrone sulphate and unconjugated oestrogens by oestradiol and oestrone. Due to the high volumes of ejaculates, amounts up to $11.5 \mu \mathrm{g}$ ( $5 \mu \mathrm{g}$ oestradiol, $2 \mu \mathrm{g}$ oestrone and $4.5 \mu \mathrm{g}$ oestrone sulphate) have been measured in semen (Hoang-Vu, 1987). Such amounts are likely to exert physiological reactions in the female.

\section{Influence of seminal oestrogens on uterine contractions}

Spontaneous uterine contractions are under the control of progesterone and oestrogens, as also shown for the pig by measuring the electromyographic activity throughout the cycle (Claus ef al., 1989). In the ewe and the rabbit intramuscular application of oestradiol improved sperm transport and higher numbers of spermatozoa were recovered from the uterus and oviduct (Hawk \& Cooper, 1976; Hawk et al., 1975). In the pig, seminal plasma increases uterine contractions, but this effect could not be ascribed to specific seminal components (Einarsson \& Viring, 1973).

The infusion of $100 \mathrm{ml}$ saline with or without oestrogens in amounts which physiologically occur in semen of boars (see above) influenced the electrical myometrial activity. The frequency of contractions increased significantly about 2-fold after both treatments, whereas the duration remained unchanged at $30 \mathrm{sec}$. The increase in frequency tended to be higher after saline with oestrogens. Mechanical stimulation of the cervix by transcervical infusion of $100 \mathrm{ml}$ saline also increased the contraction frequency.

The infusion of volumes of only $10 \mathrm{ml}$ through uterine lumen catheters excluded mechanical stimulation and clearly demonstrated that oestrogens specifically increase the contraction frequency in the sow (Fig. 2; see also Fig. 8). Compared with the spontaneous contraction frequency 


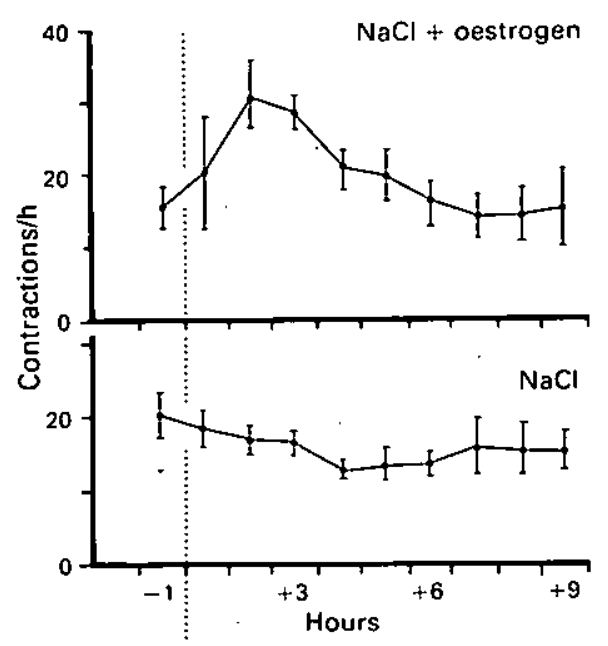

Fig. 2. Hourly means ( \pm s.e.m.) of the contraction frequency (electrical myometrial activity) after intrauterine infusion (vertical dotted linc) of $10 \mathrm{ml}$ saline with $(\mathrm{N}=4)$ or without $(\mathrm{N}=4)$ the addition of $11.5 \mu \mathrm{g}$ oestrogens. (After Hoang-Vu, 1987; Claus et al., 1989.)

at Day 0 this increase was about 2-fold and significant from the 2nd until the 4th hour after infusion.

These results explain why natural mating and $\mathrm{Al}$ lead to increased contraction frequencies of the myometrium (Döcke \& Worch, 1963; Zerobin, 1968; Bower, 1974). The effect of a mechanical stimulation also explains why volumes of at least $50 \mathrm{ml}$ are required to obtain suitable results with AI (Stratman \& Self, 1960). The specific effect of seminal oestrogens, which is independent of volume, may be regarded as a biological safety mechanism for cases of low ejaculate volumes and loss due to cervical backflow.

A release of oxytocin via the Ferguson reflex due to mechanical stimulation of the genital tract has been shown in cows (Schams et al., 1982). In the pig mating led to a dramatic increase of oxytocin in peripheral plasma (see Fig. 8), whereas 'insemination' of $100 \mathrm{ml}$ saline increased oxytocin only in 1 of 6 sows (R. Claus \& D. Schams, unpublished observations). Therefore, the increase in the contraction frequency after 'insemination' of $100 \mathrm{ml}$ saline is probably due to a stimulation of mechanical receptors similar to the induction of peristaltic contractions of the digestive tract in response to the volume of food (Hunt \& McDonald, 1954).

\section{Influence of seminal oestrogens on uterine release of PGF-2 $\alpha$}

It is known that PGF- $2 \alpha$ stimulates the contractions of the myometrium in various species (Patil et al., 1980; Garcia-Villar et al., 1985). Oestrogens stimulate the synthesis and release of PGF-2 $\alpha$ by the endometrium (Ham et al., 1975; Pakrasi et al., 1983; Jouanen et al., 1985).

Intrauterine application of $10 \mu \mathrm{g}$ amounts of oestrogens (oestrone, oestradiol or oestrone sulphate: simulation of seminal oestrogens) during total anaesthesia may lead to a sudden rise of the PGF- $2 \alpha$ concentrations in the uterine vein within $1 \mathrm{~min}$ after infusion (Claus et al., 1987). A coincident increase of uterine contraction waves in the tubal direction was clearly visible on the exteriorized uterus.

Infusion of oestrogens to a limited number of conscious sows with chronic catheterization of a uterine vein clearly confirmed the uterine origin (Fig. 3). Additionally, these experiments showed that oestradiol leads to a specific rise in the PGF-2 $\alpha$ concentrations when infused at Day 0 , but 


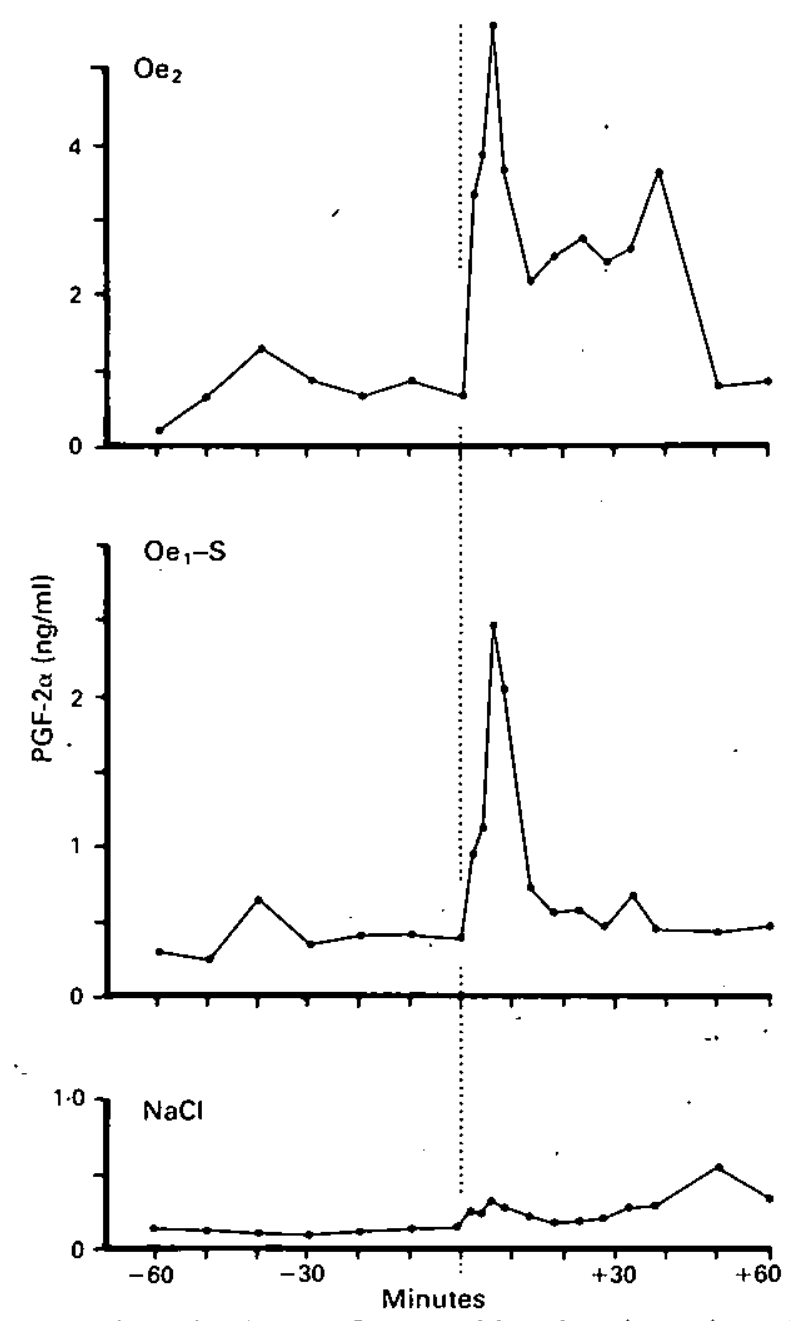

Fig. 3. PGF-2 $\alpha$ in the uterine vein plasma of a sow with a chronic uterine vein catheter. Transcervical infusions (vertical dotted line) of $100 \mathrm{ml}$ saline $(\mathrm{NaCl})$ or saline with the addition of $10 \mu \mathrm{g}$ oestrone sulphatc $\left(\mathrm{Oc}_{1}-\mathrm{S}\right)$ or $10 \mu \mathrm{g}$ oestradiol-17ß $\left(\mathrm{Oe}_{2}\right)$ were carried out at Day 0 of consecutive cycles (Claus et al., 1988).

not 1 day later (R. Claus, H. D. Meyer, T. Gimenez, C. Hoang-Vu \& E. Münster, unpublished observations).

Measurements of the prostaglandin metabolite (PGFM) in peripheral plasma confirmed this specific effect of oestrogens on PGF-2 $\alpha$ release. A dramatic increase was measurable after infusion of $10 \mu \mathrm{g}$ oestradiol in saline and after natural mating. with intact boars. Treatment with $100 \mathrm{ml}$ saline led to only a slight increase. With natural mating the period of increased concentrations was extended up to $4 \mathrm{~h}$ (example included in Fig. 8). The resulting biphasic pattern of elevated PG concentrations is probably explained by the binding of oestrogens to spermatozoa. Free oestrogens may be responsible for a first rapid increase, whereas the release of sperm-bound oestrogens.leads to a prolonged period of high PGFM concentrations. This might lead to prolonged periods of increased uterine contractions.

Thus seminal oestrogens, via PGF-2 $\alpha$, improve sperm transport and are an important part of the regulating system leading to fertilization. Additional mechanisms, however, are required to optimize the time of ovulation in relation to sperm deposition in the uterus. 


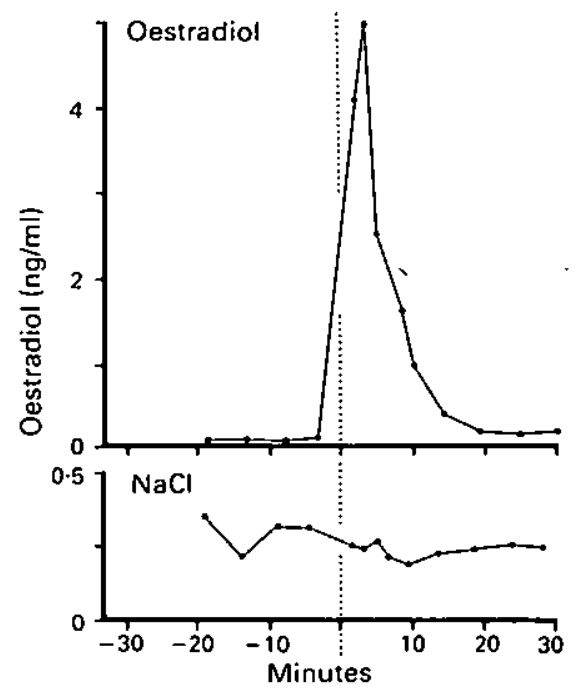

Fig. 4. Oestradiol- $17 \beta$ concentrations in the uterine vein plasma of 2 sows under total anaesthesia before and after transcervical infusion (vertical dotted line) of either $100 \mathrm{ml}$ saline $(\mathrm{NaCl})$ or saline with the addition of $10 \mu \mathrm{g}$ oestradiol-17ß. (After Claus et al., 1987.)

\section{Do seminal oestrogens influence ovulation?}

The presence of the boar is partly effective in influencing the timing of events. Oestrus in relation to the oestradiol maximum occurred earlier in sows kept in the presence of boars than in the absence of boars. Also, LH concentrations were significantly higher at maximal standing refiex $(2.62 \pm 1.65$ vs $0.99 \pm 0.67 \mathrm{ng} / \mathrm{ml})$ under boar stimulation (Claus, 1989). Similarly, the LH peak occurred more in synchrony with oestrus in sows with extensive boar contact (Kirsch el al., 1985). Boar exposure also induces prolactin peaks, which could play a role in oestrous behaviour (Prunier et al., 1987).

Apart from the boar's presence, mating itself provides additional stimuli and shortens both the interval from onset of oestrus to ovulation and the duration of ovulation (Signoret et al., 1972). Higher concentrations of $\mathrm{LH}$ in blood were measured immediately after mating (Guthrie $e t$ al., 1972; Tilton et al., 1980) and coitus prolonged the LH surge (Ziecik et al., 1981).

Simulation of seminal oestrogens by intrauterine infusion of $10 \mu \mathrm{g}$ amounts of oestrogens in saline at Day 0 increased the oestrogen concentrations in blood plasma. A rise in uterine vein plasma (see Fig. 4) occurred within minutes after infusion and also in peripheral plasma with a maximum at about $10 \mathrm{~min}$. On average, infusion of $10 \mu \mathrm{g}$ oestradiol in $100 \mathrm{ml}$ saline in 6 sows led to a $37 \%$ increase in peripheral oestradiol $(P<0.001)$ concentration and additionally to a $55 \%$ increase of oestrone sulphate $(P<0.001)$. A dose of $10 \mu \mathrm{g}$ oestrone increased peripheral oestrone concentrations by $13 \%(P<0.001)$ and oestrone sulphate by $25 \%(P<0.001)$. In contrast, oestrone sulphate and saline had no effect (Claus et al., 1987). After mating with intact boars high peripheral concentrations of oestradiol were also measurable (example, Fig. 8).

Such a peripheral oestrogen increase, superimposed on the endogenous levels, may be involved in the positive feedback leading to the LH surge and ovulation.

'Insemination' of sows kept without boar contact with $10 \mu \mathrm{g}$ oestradiol in $100 \mathrm{ml}$ saline at Day 0 indeed seems to influence $\mathrm{LH}$ release, but not necessarily ovulation as demonstrated with 2 extreme examples (Figs $5 \& 6$ ). Figure 5 represents an insemination at maximal standing reflex which occurred during the drop of peripheral oestradiol values and already increased LH concentrations. Oestradiol 'insemination' amplified the peripheral increase of oestradiol and seemed to stimulate an additional $\mathrm{LH}$ release. In another sow, standing heat occurred when oestradiol had already dropped 


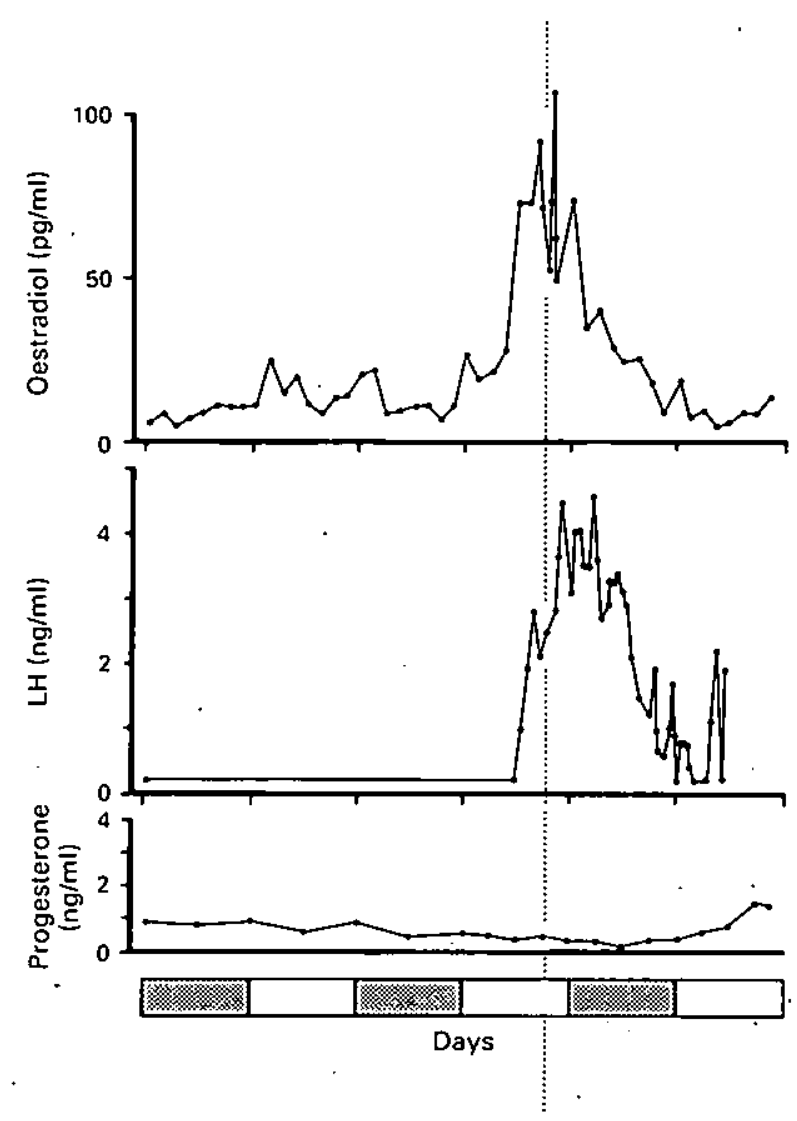

Fig. 5. Profiles of oestradiol-17ß, LH and progesterone in a sow without boar contact. Transcervical infusion of $10 \mu \mathrm{g}$ oestradiol (vertical dotted line) at the day of maximal standing reflex led to an additional increase in oestradiol and LH. The LH concentrations were below the assay sensitivity before the preovulatory rise and were still elevated during rising progesterone (R. Claus, C. Hoang-Vu \& U. Weiler, unpublished observations).

(Fig. 6). Infusion with oestradiol led to oestradiol concentrations above the preovulatory level and induced an LH release when progesterone was already rising. Apparently ovulation had occurred in the presence of low LH concentrations. Seminal oestrogens may therefore lead to LH release. This LH surge might influence ovulation if the presence of the boar leads to the proper timing of behavioural oestrus. In addition, a supporting role of PGF $-2 \alpha$ for ovulation has to be considered (see Lipner, 1988).

Follicles respond to the preovulatory LH surge with an increased intrafollicular prostaglandin synthesis. These prostaglandins stimulate the activity of enzymes, such as collagenase and elastase (Evans et al., 1983), which are involved in follicular rupture (see Lipner, 1988). In the pig the increase of enzyme activity before ovulation has been demonstrated. A parallel preovulatory rise of PGF-2 $\alpha$ and PGE-2 has been measured in the follicular fluid (Ainsworth et al., 1975; Armstrong, 1981; Evans et al., 1983; Gimeno et al., 1985; Hunter \& Poyser, 1985).

The inhibition of prostaglandin synthesis, e.g. by indomethacin, is effective in inhibiting ovulation in the rabbit (Okamura et al., 1985), the rat (Tsafriri et al., 1972) and the pig (Ainsworth et al., 1979; Downey \& Ainsworth, 1980; Yamada et al., 1984) but not in women (Landgren et al., 1985). Substitution of PGF-2 $\alpha$ but not of PGE-2 in indomethacin-blocked pigs reversed the ovulation blockade (Downey \& Ainsworth, 1980). 


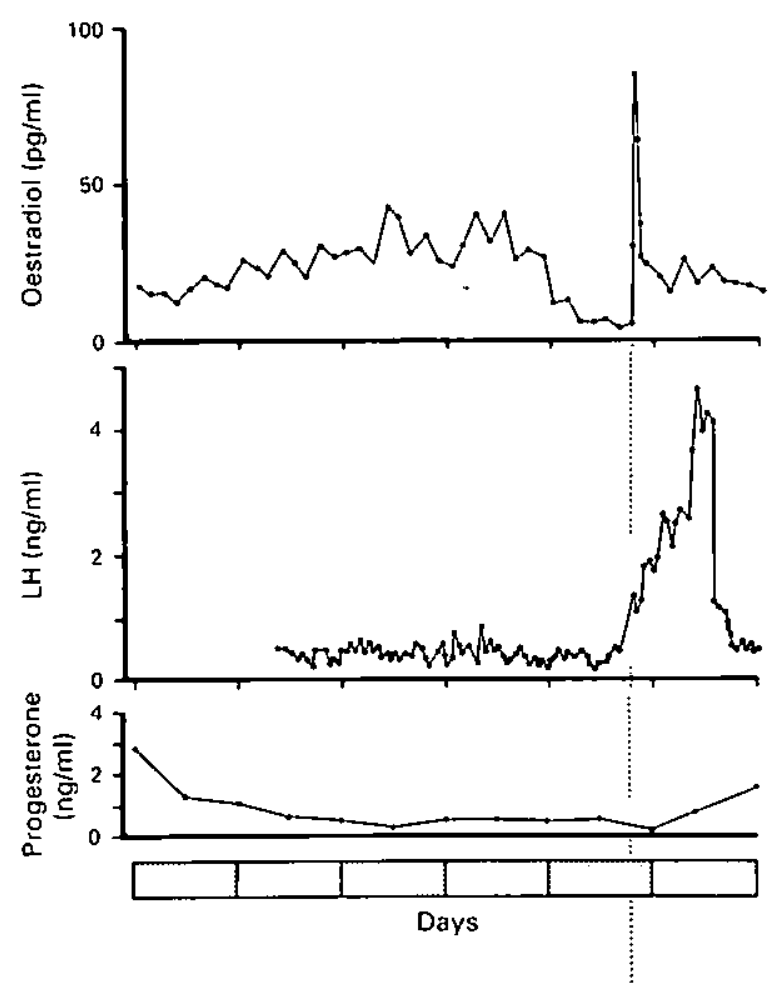

Fig. 6. Profiles of oestradiol-17 $\beta, \mathrm{LH}$ and progesterone in a sow without boar contact. The drop in oestradiol occurred in the presence of low LH. Transcervical infusion of $10 \mu \mathrm{g}$ oestradiol (vertical dotted line) at the day of maximal standing reflex increased peripheral oestradiol and $\mathrm{LH}$ values. Maximal $\mathrm{LH}$ concentrations occurred during rising progesterone ( $\mathrm{R}$. Claus, $\mathrm{C}$. Hoang-Vu \& U. Weiler, unpublished observations).

Uterine PGF-2 $\alpha$ reaches the ovary by countercurrent exchange to induce luteolysis. In the pig, the lymphatic circulation also seems to ensure transport to the contralateral ovary (Kotwica $e t a l$, 1983). Uterine PGF-2 $\alpha$ is slightly elevated at Day 0 (see also Fig. 8) and is further increased by the presence of seminal oestrogens. Apparently PGF-2 $\alpha$ reaches the follicles and contributes to intrafollicular PGF- $2 \alpha$ concentrations. Parallel measurements in uterine vein and ovarian artery after uterine oestradiol infusion demonstrated the effectiveness of these transfer mechanisms during oestrus. Additionally, infusion of $\left[{ }^{3} \mathrm{H}\right] \mathrm{PGF}-2 \alpha$ into a uterine vein and partial recovery in the follicular fluid confirmed these transfer mechanisms (Claus, 1989).

Experiments were first carried out to see whether uterine PG release contributed to ovulation (Zöttl, 1988). Sows were pretreated with indomethacin during the follicular phase (experimental details see Fig. 7). In one group uterine PGF-2 $\alpha$ release was simulated by an infusion of $5 \mathrm{mg}$ PGF- $2 \alpha$ into the uterus. Figure 7 shows that indomethacin treatment effectively suppressed PGFM concentrations in peripheral plasma, compared with the controls. Infusion of PGF-2 $\alpha$ led to a peripheral rise of PGFM, which was similar in magnitude to the increased concentrations found after infusion of oestradiol into the uterus. In contrast to other studies (Downey \& Ainsworth, 1980) all sows ovulated and remained cyclic. The treatments, however, were effective in changing the time-relationships between the LH surge, the drop in oestradiol, and the increase in progesterone which reflects ovulation (Table 1). Indomethacin, compared with controls, increased the interval from the $\mathrm{LH}$ maximum until a decrease of oestradiol below $20 \mathrm{pg} / \mathrm{ml}$ for more than 1 day. Similarly the period from the LH maximum until an increase of progesterone above $1 \mathrm{ng} / \mathrm{ml}$ 


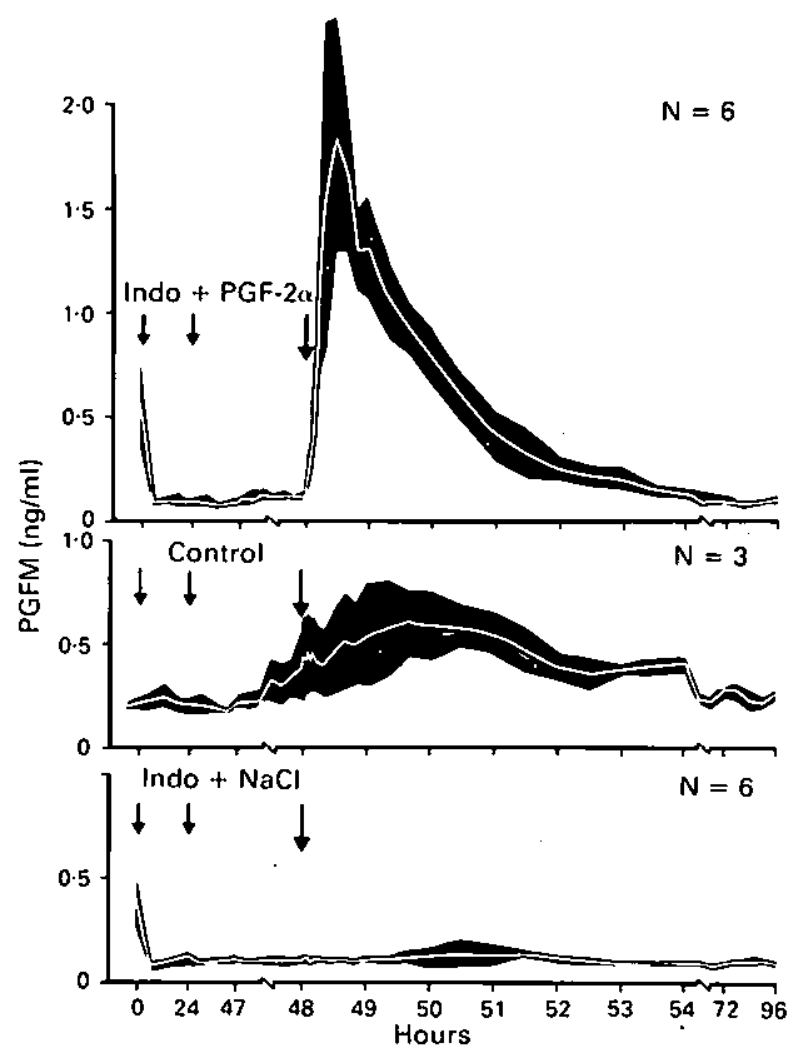

Fig. 7. PGFM concentrations (mean \pm s.e.m.) in peripheral plasma of sows which were injected i.m. (arrows) with $7.5 \mathrm{mg}$ indomethacin (Indo) $/ \mathrm{kg}$ bodyweight at 0,24 and $48 \mathrm{~h}$ (Hour $0=2$ days after decrease of progesterone below $2 \mathrm{ng} / \mathrm{ml}$ ). Intrauterine infusions were carricd out with $200 \mathrm{ml}$ saline (Indo $+\mathrm{NaCl}$ ) or $200 \mathrm{ml}$ saline $+5 \mathrm{mg}$ PGF-2 $\alpha$ (Indo + PGF-2 $\alpha$ ) at Hour 48. Untreated sows served as controls. (From Zöttl, 1988.)

increased from 18 to $51 \mathrm{~h}$. Although concentrations of progesterone were identical in all groups 2 days before the first indomethacin treatment (Day 0, see Fig. 7), significant differences became obvious between Days 6 and 7 between controls and those treated with indomethacin $+\mathrm{NaCl}$ (Table 1). Additional application of PGF-2 $\alpha$.resulted in at least partly normal time relationships and differences between the two groups were not significant. This pilot study, with only a few sows included, so far at least supports the hypothesis that PGF-2 $\alpha$, as a consequence of seminal oestrogens, is also active at the ovarian level.

\section{Effects of seminal components on the female immune system}

The mechanisms described so far for seminal oestrogens contribute to an optimization of the time relationships leading to fertilization. Quantitative aspects such as a high survival rate of spermatozoa in the female genital tract also contribute to a high fertility (Polge, 1978). In some animal species a lowered fertility due to immune reactions of the female have been reported (see Veselsky et al., 1981).

As in other species, sperm surface proteins and glycoproteins of the boar play an important role in capacitation, the acrosome reaction, the interaction with the egg zona and the fusion with the egg plasma membrane (Fléchon, 1979; Peterson et al., 1984, 1987; Saxena et al., 1986; Klint et al., 

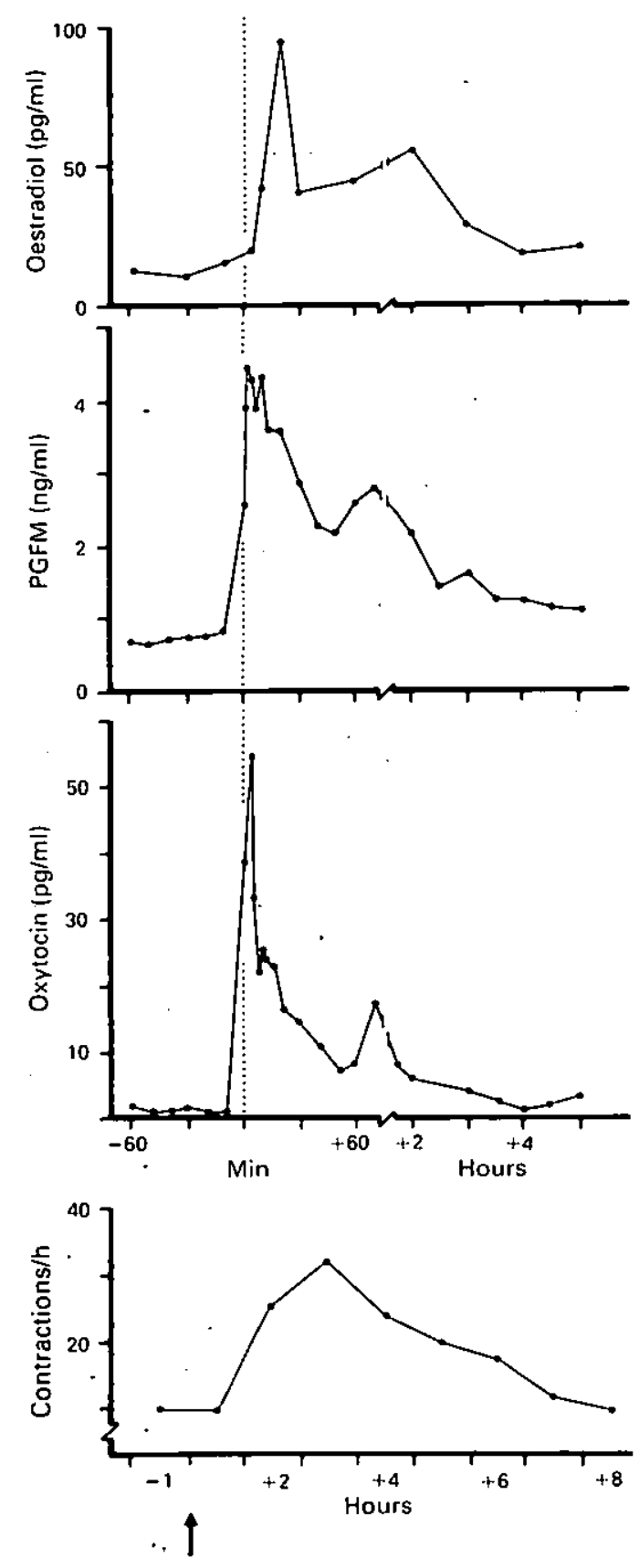

Fig. 8. Oestradiol-17 $\beta$, PGFM and oxytocin concentrations in a sow before and after natural mating (vertical dotted line). For comparison, the electromyographic activity of another sow before and after insemination (arrow) with $100 \mathrm{ml}$ of an ejaculate is included. (After Claus $e t$ al., 1988; Hoang-Vu, 1987; and R. Claus \& D. Schams, unpublished data.)

1987). Surface modifications occur during spermatogenesis (Klint et al., 1987) and epididymal maturation (Saxena et al., 1986), and secretions of the accessory sex glands at ejaculation contribute to the sperm membrane polypeptide profile (Russell et al., 1984). The continuous changes in 
Table 1. Relationships (mean \pm s.d.) between endocrine events around ovulation in untreated sows (controls) and sows in which the endogenous prostaglandin synthesis was blocked by indomethacin instilled with saline or PGF-2 $\alpha(5 \mathrm{mg})$ into the uterus

\begin{tabular}{|c|c|c|c|}
\hline \multirow[b]{3}{*}{$\begin{array}{l}\text { LH-oestradiol }<20 \mathrm{pg} / \mathrm{ml} \\
\text { (h) }\end{array}$} & \multirow[b]{2}{*}{$\begin{array}{l}\text { Controls } \\
(\mathrm{N}=3)\end{array}$} & \multicolumn{2}{|c|}{ Indomethacin } \\
\hline & & $\begin{array}{l}\text { PGF-2a } \\
(N=5)\end{array}$ & $\begin{array}{c}\mathrm{NaCl} \\
(\mathrm{N}=5)\end{array}$ \\
\hline & $24 \pm 11^{*}$ & $31 \pm 14^{2}$ & $57 \pm 23^{\circ}$ \\
\hline $\begin{array}{l}\text { LH-progesterone }>\lfloor\mathrm{ng} / \mathrm{ml} \\
\text { (h) }\end{array}$ & $18 \pm 22^{\mathrm{a}}$ & $28 \pm 25^{a b}$ & $51 \pm 3^{b c}$ \\
\hline $\begin{array}{l}\text { Progesterone at Day } 6 \\
(\mathrm{ng} / \mathrm{ml})\end{array}$ & $5 \cdot 3 \pm 1 \cdot 2^{n}$ & $4 \cdot 8 \pm 1 \cdot 1^{2 b}$ & $3.4 \pm 0.8^{b c}$ \\
\hline $\begin{array}{l}\text { Progesterone at Day } 7 \\
(\mathrm{ng} / \mathrm{ml})\end{array}$ & $7.4 \pm 1.8^{a}$ & $5.4 \pm 1 \cdot 1^{\text {ab }}$ & $4 \cdot 2 \pm 1 \cdot 0^{b e}$ \\
\hline
\end{tabular}

Values with a different superscript letter are significantly different, $P<0.05$.

sperm surface proteins within the male genital tract partly explain why a low probability exists that spermatozoa are eliminated by autoimmune responses (see Haas \& Beer, 1986).

These surface structures are also potential antigens within the female reproductive tract (e.g. Haas \& Beer, 1986; Ansbacher, 1981). In domestic animals, however, the danger of immunization of the female is substantially smaller than in man because individuals are mated or inseminated only a few times during their reproductive lives (Matousek, 1985).

Immunization of sows with boar spermatozoa has led to detectable antisperm-antibody titres, but subsequent mating did not demonstrate an effect on the sow's fertility (Veselsky et al., 1981). The rapid transport of spermatozoa through the uterus of the sow may help to protect spermatozoa against immunological attack. Additionally, immunosuppressive mechanisms die to seminal components have to be considered as has been shown in the rat (Stites \& Erickson, 1975). An immunosuppressive factor in boar semen is derived from the seminal vesicles (Stanek et al., 1985). Intrauterine deposition of killed semen in addition to normal semen or before mating increased reproductive efficiency in gilts (Murray et al., 1983; Murray \& Grifo, 1986) and may point to an immunosuppressive function of boar semen.

The rosette inhibition test (RIT: inhibition of the formation of spontaneous rosettes between lymphocytes and heterologous erythrocytes by antilymphocyte sera) is considered to reflect an immunosuppression and has been used to demonstrate an early pregnancy factor in the pig as early as 4-6 h after mating (Koch et al., 1983; Koch \& Ellendorff, 1985a). It has been shown, however, that mating with a vasectomized boar as well as intracervical infusion of seminal plasma led to an inhibition of rosette formation up to $24 \mathrm{~h}$ after mating. Similarly, preincubation of pig lymphocytes with dilutions of seminal plasma was also effective (Koch \& Ellendorff, 1985b), confirming that these effects are due to immunosuppressive functions of boar seminal plasma.

Several components in seminal plasma have been discussed as possible candidates for an immunosuppressive function in other species, including opioid peptides which could, for example, explain an inhibitory effect of semen on human lymphocyte T rosette formation (Shu-Dong et al., 1982). This effect is prohibited by naloxone (see Fabbri et al., 1986). Prostaglandins have also been considered as likely candidates (see Stites \& Erickson, 1975), because natural killer cell function is inhibited by 19-hydroxy-PGE in human seminal plasma (see Aitken et al., 1986). Additionally, oestradiol induces a significant decline in immunoglobulins which has been demonstrated in the genital tract of various species (see Haas \& Beer, 1986). This, however, does not automatically point to another role of seminal oestrogens, because they disappear soon after AI or natural mating. 
Bovine seminal plasma has an immunosuppressive activity against mouse and bovine lymphocytes (see Fahmi et al., 1985). This inhibitory effect has been attributed to proteins with molecular weights of 50000, 100000 and 150000 (Prakash et al., 1976; Fahmi et al., 1985). Similar proteins have also been found in human seminal plasma (Pitout \& Jordaan, 1976). Immunosuppressive proteins have been detected in boar seminal plasma: one has a molecular weight of $>500000$ and another has an $M_{\mathrm{r}}$ of $100000-110000$. The former seems to be an aggregation of the latter protein (Bouvet et al., 1986). Most of the immune functions, with the exception of killer cell activity, are suppressed by this protein (Bouvet et al., 1987). Pronase digestion down to fragments of $M_{\mathrm{r}}$ 2000-5000 did not change optimal immunosuppressive activity.

It is likely that these functions are not only limited to the protection of spermatozoa during their rapid transport through the uterus. Rosette inhibiting function after mating with a vasectomized boar was maintained up to $48 \mathrm{~h}$ after mating (Koch \& Ellendorff, 1985b). These mechanisms might also therefore protect the embryos against immune attack until they have developed their own ability to suppress the immune system of the sow, e.g. by release of an early pregnancy factor.

An immunosuppression seems to be a doubtful mechanism, however, in a species in which ejaculation occurs into the uterus and an elimination of microbes is necessary. In the bull an antimicrobial protein (seminal plasmin) has been detected (Scheit et al., 1979). It effectively inhibits the growth of a variety of Gram-positive and Gram-negative bacteria as well as of yeast cells (Scheit et al., 1979). A synthetic DNA coding for this protein has been obtained and cloned in E. coli (Preuss et al., 1987). So far, however, boar semen has not been analysed for this substance.

Studies on seminal oestrogen function, including unpublished observations, were supported by the Deutsche Forschungsgemeinschaft.

\section{References}

Ainsworth, L., Baker, R.D. \& Armstrong, D.T. (1975) Pre-ovulatory changes in the follicular fluid prostaglandin F levels in swine. Prostaglandin 9, 915-925.

Ainsworth, L., Tsang, B.K., Downey, B.R., Baker, R.D., Marcus, G.J. \& Armstrong, D.T. (1979) Effects of indomethacin on ovulation and luteal function in gilts. Biol. Reprod. 21, 40l-411.

Aitken, R.J., Irvine, S. \& Kelly, R.W. (1986) Significance of intracellular calcium and cyclic adenosine $3^{\prime}, 5^{\prime}$. monophosphate in the mechanisms by which prostaglandins influence human sperm function. $J$. Reprod. Ferl. 77, 451-462.

Allag, I.S., Das, R.P. \& Roy, S. (1983) The binding patterns of antisera to sex steroids and human gonadotropins on human and rhesus monkey spermatozoa. J. Androl. 4, 415-420.

Ansbacher, R. (1981) Sperm antibodies and infertility. Feri. Sieril. 36, 446-447.

Armstrong, D.T. (1981) Prostaglandins and follicular functions. J. Reprod. Fert. 62, 283-291.

Baker, R.D., Dziuk, P.J. \& Norton, H.W. (1968) Effect of volume of semen, number of sperm and drugs on transport of sperm in artificially inseminated gilts. $J$. Anim. Sci. 27, 88-93.

Bedford, J.M. (1970) Sperm capacitation and fertilization in mammals. Biol. Reprod. 2 (Suppl. 2), I28158.

Bouvet, J.-P., Couderc, J., Parlebas, J., Pirès, R., Duclos, H. \& Pillot, J. (1986) Mise en évidence d'une fraction immunosuppressive de $100-110 \mathrm{kd}$ dans le liquide spermalique de porc. C. r. hebd. Séanc, Acad. Sci. Paris 302, 233-238.

Bouvet, J.P., Couderc, J. \& Pillot, J. (1987) In vivo and in vitro immunosuppressions in mice by a $100-110 \mathrm{kd}$ fraction from boar seminal plasma. $A \mathrm{~m}$. J. Immunol. Microbiol. 14, 135-140.

Bower, R.E. (1974) Factors affecting myometrial activity in the pig. Ph.D. thesis, University Minnesota.

Brandt, H. \& Glodek, P. (1984) Der EinfluB der künstlichen Besamung auf die Wurfgrößc bcim Schwein. Züchtungskunde 56, 27-..35.

Chang, M.C. \& Hunter, R.H.F. (1975) Capacitation of mammalian sperm: biological and experimental aspects. In Handbook of Physiology. Section 7, Endocrinology V, Ch. 16 pp. 339-35I. Eds D. W. Hamilton \& R. O. Greep. American Physiological Society, Washington, D.C.

Claus, R. (1989) Oestrogens of the boar: effects on male and female reproductive funclions. In Reproduction Biology and Medicine, 136-147. Eds A. F. Holstein, K. D. Voigt \& D. Grässlin. Diesbach Verlag, Berlin.

Claus, R., Schopper, D. \& Wagner, H.-G. (1983) Seasonal effect on steroids in blood plasma and seminal plasma of boars. J. Sieroid Biochem. 19, 725-729.

Claus, R., Schopper, D. \& Hoang-Vu, C. (1985) Contribution of individual compartments of the genital tract to oestrogen and testosterone concentrations in ejaculates of the boar. Acta endocr., Copenh. 109, 281-288.

Claus, R., Hoang-Vu, C., Ellendorf, F., Meyer, H.D., Schopper, D. \& Weiler, U. (1987) Seminal oestrogens 
of the boar: origin and functions in the sow. $J$. Steroid Biochem. 27, 331-335.

Claus, R., Hoang-Vu, C., Ellendorff, F., Meyer, H.D. \& Giménez, T. (1988) Effects of boar seminal oestrogens on uterine contractions and prostaglandin release in the sow. Proc. I/th Int. Congr. Anim. Reprod. \& AI. Dublin, Vol. 2, 17.

Claus, R., Ellendorff, F. \& Hoang-Vu, C. (1989) Spontaneous electronmyographic activity throughout the cycle in the sow and its change by intrauterine oestrogen infusion during oestrus. J. Reprod. Fert. 87, 543-551.

Döcke, F. \& Worch, H. (1963) Untersuchungen über die Uterusmotilität und Paarungsreaktionen der Sau. Zuchthygiene 7, 169-178.

Downey, B.R. \& Ainsworth, L. (1980) Reversal of indomethacin blockade of ovulation in gilts by prostaglandins. Prostaglandins 19, 17-22.

Einarsson, S. \& Viring, S. (1973) Effect of boar seminal plasma on the porcine uterus and the isthmus part of oviducts in vitro. Acta vet. scand. 14, 639-641.

Evans, G., Dobias, M., King, G.J. \& Armstrong, D.T. (1983) Production of prostaglandins by porcine preovulatory follicular tissues and their roles in intrafollicular function. Biol. Reprod. 28, 322-328.

Fabbri, A., Fraioli, F. \& Isidori, A. (1986) Opioid peptides in the testis and the male genital tract: presence and possible function. J. endocrinol. Invest. 9, 521-528.

Fahmi, H.A., Hunter, A.G., Markham, R.J.F. \& Seguin, B.E. (1985) Identification of an immunosuppressive protein in bovine seminal plasma with activity against bovine lymphocytes. J. Dairy Sci. 68, 2322-2328.

First, N.L., Short, R.E., Peters, J.B. \& Stratman, F.w. (1968a) Transport of boar spermatozoa in estrual and luteal sows. J. Anim. Sci. 27, 1032-1036.

First, N.L., Short, R.E., Peters, J.B. \& Stratman, F.W. (1968b) Transport and loss of boar spermatozoa in the reproduclive tract of the sow. J. Anim. Sci. 27, 1037-1040.

Fléchon, J.-E. (1979) Sperm glycoproteins of the boar, bull, rabbit, and ram: II. Surface glycoproteins and free acidic groups. Gamele Res. 2, 53-64.

Fléchon, J.E. \& Hunter, R.H.F. (1981) Regulation of sperm transport by the utero-tubal junction and isthmus in pigs: a scanning electron microscope study. Tissue and Cell 13, 127-139.

Foxcroft, G.R. \& van de Wiel, D.F.M. (1982) Endocrine control of the oestrous cycle. In Control of Pig Reproduction, pp. 161-177. Eds D. J. A. Cole \& G. R. Foxcroft. Butterworth, London.

Garcia-Villar, R., Marnet, P.G., Laurentie, M.P. \& Toutain, P.L. (1985) Relative oxytocic properties of fenprostalene compared with cloprostenol, prostaglandin $F_{i a}$, and oxylocin in the ovariectomized ewe. Am. J. vet. Res. 46, 84I-844.

Gimeno, M.F., Franchi, A.M., Sterin-Speziale, N.B., Gonzalez, S.T., Speziale, E.H. \& Gimeno, A.L. (1985) Sow (Sus Scrofa) follicular fluid: prostaglandin content and effect on the motility of isolated oviducts. Prostaglandins 20, 831-845.

Guthrie, H.D., Henricks, D.M. \& Handlin, D.L. (1972) Plasma oestrogen. progesterone and luteinizing hormone prior to estrus and during early pregnancy in pigs. Endocrinology 91, 675-679.
Haas, G.G., Jr \& Beer, A.E. (1986) Immunologic influences on reproductive biology: sperm gamelogenesis and maturation in the male and female genital tracts. Fert. Steril. 46, 753-765.

Ham, E.A., Cirillo, V.J., Zanetti, M.E. \& Kuehl, F.A., Jr (1975) Estrogen-directed synthesis of specific prostaglandins in uterus. Proc. natn. Acad. Sci. USA 72, 1420-1424.

Hashizume, T. (1984) The origin of prostaglandin $F_{20}$ in bull and boar semen. Jap. J. Zoot. Sci. 55, $540-544$.

Hawk, H.W. \& Cooper, B.S. (1976) Improvement of sperm transport by the administration of estradiol to estrous ewes. J. Anim. Sci. 41, 1400-1406.

Hawk, H.W., Cooper, B.S. \& Conley, H.H. (1975) Effect of acetylcholine, prostaglandin $F_{z a}$ and estradiol on number of sperm in the reproductive tract of inseminated rabbits. J. Anim. Sci. 55, 891-900.

Hoang-Vu, C. (1987) Elektrische Aktivität des Myometriums beim Schwein während des Zyklus und ihre Beeinflussung durch Infusion von Östrogenen in das Uieruslumen am Tag der Rausche. Thesis, Sci. agr., University Hohenheim.

Hunt, J.N. \& McDonald, I. (1954) The influence of volume on gastric emptying. $J$. Physiol., Lond. 126, 459-474.

Hunter, R.H.F. (1973) Transport, migration and survival of spermatozoa in the female genital tract: species with intrauterine deposition of semen. In Sperm Transport, Survival and Fertilizing Ability, pp. 309-342. Eds E. S. E. Hafez \& C. Thibault. INSERM, Paris.

Hunter, R.H.F. (1982) Interrelationships between spermatozoa, the female reproductive tract, and the egg investment. In Control of Pig Reproduction. pp. 49-63. Eds D. J. A. Cole \& G. R. Foxcroft. Butterworth, London.

Hunter, R.H.F. (1984) Pre-ovulatory arrest and periovulatory redistribution of competent spermatozoa in the isthmus of the pig oviduct. J. Reprod. Fert. 72, 203-2I1.

Hunter, R.H.F. \& Dziuk, P.J. (1968) Sperm penetration of pig eggs in relation to the timing of ovulation and insemination. J. Reprod. Fert. 15, 199-208.

Hunter, R.H.F. \& Poyser, N.L. (1985) Ovarian follicular fluid concentrations of prostaglandins $E_{2}, F_{20}$ and $l_{2}$ during the pre-ovulatory period in pigs. Reprod. Nurr. Dévelop. 25, 909-917.

Imai, H., Niwa, K. \& Iritani, A. (1979) Time requirement for capacitation of boar spermatozoa assessed by their ability to penetrate the zona-free hamster egg. $J$. Reprod. Fert. 56, 489-492.

Jouanen, A., Saintot, M., Thaler-Dao, H. \& Crastes de Paulet, A. (1985) Prostaglandin synthesis from endogenous and exogenous arachidonic acid in the rat uterus. Effect of estradiol and progesterone. Prostaglandins Leukotrienes Med. 18, 321-336.

Kirsch, J.D., Tilton, J.E., Ziecik, A., Weigl, R., Schaffer, T. \& Williams, G.L. (1985) Effects of various mating stimuli on pituitary release of luteinizing hormone in the gilt. Dom. Anim. Endocrinol. 2, 99-104.

Klint, M., Fridberger, A., Menge, A., Sällström, J. \& Plöen, L. (1987) Boar sperm surface glycoproteins: isolation, localization, and temporal expression during spermatogenesis. Gamete Res. 17, 173-190. 
Koch, E. \& Ellendorff, F. (1985a) Prospects and limitations of the rosette inhibition test to detect activity of early pregnancy factor in the pig. J. Reprod. Fert. 74, 29-38.

Koch, E. \& Ellendorf, F. (1985b) Detection of activity similar to that of early pregnancy factor after mating sows with a vasectomized boar. $J$. Reprod. Ferr. 74, $39-46$.

Koch, E., Morton, H. \& Ellendorf, F. (1983) Early pregnancy factor: biology and practical application. $B r$. vet. J. 139, 52-58.

Kotwica, J., Krzymowski, T., Stefanczyk, S., Koziorowski, M., Czarnocki, J. \& Ruszczyk, T. (1983) A new route of prostaglandin $\mathrm{F}_{\mathrm{a}}$ transfer from the uterus into the ovary in swine. Anim. Reprod. Sci. 5, 303-309.

Landgren, B.M., Lundstrōm, V., Eneroth, P. \& Johanisson, E. (1985) The effect of a prostaglandin synthetase inhibitor on the hormonal profile and the endometrium in women. Am. J. Obstet. Gynecol. 151, 361-368.

Lipner, H. (1988) Mechanism of mammalian ovulation. In Physiology of Reproduction, pp. 447-487. Eds E. Knobil \& J. Neill. Raven Press, New York.

Lovell, J.E. \& Getty, R. (1968) Fate of semen in the uterus of the sow: histologic study of the endometrium during the 27 hours after natural service. $\mathrm{Am}$. J. vet. Res. 29, 609-625.

Mann, T. \& Lutwak-Mann, C. (1981) Male Reproductive Function and Semen. Springer, Berlin.

Matousek, J. (1985) Biological and immunological roles of proteins in the sperm of domestic animals (review). Anim. Reprod. Sci. 8, 1-40.

Murray, F.A. \& Grifo, A.P., Jr (1986) Intrauterine infusion of killed semen to increase litter size in gilts. $J$. Anim. Sci. 62, 187-190.

Murray, F.A., Grifo, A.P., Jr \& Parker, C.F. (1983) Increased litter size in gilts by intrauterine infusion of seminal and sperm antigens before breeding. J. Anim. Sci. 56, 895-900.

Okamura, H., Fukumoto, M. \& Mori, T. (1985) Prostaglandin-mediated changes of vasculature and collagen degradation/synthesis in the follicle wall during ovulation. Ads. Prostaglandin Thromboxane Leukoiriene Res. 15, 597-599.

Pakrasi, P.L., Chen, H.C. \& Dey, S.K. (1983) Prostaglandins in the uterus: modulation by steroid hormones. Prosiaglandins 26, 991-1009.

Patii, R.K., Sinha, S.N., Einarsson, S. \& Settergren, 1. (1980) The effect of prostaglandin $F_{2 a}$ and oxylocin on bovine myometrium in vitro. Nord. VetMed. 32, 474-479.

Peterson, R.N., Russell, L.D. \& Hunt, W.P. (1984) Evidence for specific binding of uncapacitated boar spermatozoa to porcine zona pellucida in virro. $J$. exp. Zool. 231, 137-147.

Peterson, R.N., Gillott, M., Hunt, W. \& Russell, L.D. (1987) Organization of the boar spermatozoan plasma membrane: evidence for separate domains (subdomains) of integral membrane proteins in the plasma membrane overlying the principal segment of the acrosomc. J. Cell Sci. 88, 343-349.

Pitout, M.J. \& Jordaan, J.H. (1976) Partial purification of an antimitogenic factor from human semen. $\mathrm{Imt} . J$. Biochem. 7, 149-151.

Polge, C. (1978) Fertilization in the pig and horse. $J$. Reprod. Ferı. 54, 46I-470.
Prakash, C., Coutinho, A. \& Möller, G. (1976) Inhibition of in vitro immune responses by a fraction from seminal plasma. Scand. J. Immunol. 5, 77-85.

Preuss, K.D., Sachse, H., Sharma, H.S., Hagendorff, G. \& Scheit, K.H. (1987) Molecular cloning and expression of a synthetic DNA coding for the antimicrobial protein of bull seminal plasma. Biol. Chem. HoppeSeyler 368, 501-506.

Prunier, A., Martinat-Botté, F., Ravault, J.P. \& Camous, S. (1987) Perioestrus patterns of circulating $\mathrm{LH}$, FSH, prolactin and oestradiol-17\% in the gill. Anim. Reprod. Sci. 14, 205-218.

Russell, L.D., Peterson, R.N., Hunt, W. \& Strack, L.E. (1984) Posttesticular surface modifications and contributions of reproductive tract fluids to the surface polypeptide composition of boar spermatozoa. Biol. Reprod. 30, 959-978.

Sander-Richter, H. (1986) Untersuchungen zur Oxy/ocinSekretion beim männlichen Schwein. Thesis sci. agr., University Göttingen.

Saxena, N., Peterson, R.N., Sharif, S., Saxena, N.K. \& Russell, L.D. (1986) Changes in the organization of surface antigens during in-vitro capacitation of boar spermatozoa as detected by monoclonal antibodies. J. Reprod. Fert. 78, 601-614.

Schams, D., Baumann, G. \& Leidl, W. (1982) Oxylocin determination by radioimmunoassay in cattle. 11 . Effect of mating and stimulation of the genital tract in bulls, cows and heifers. Acta endocr.. Copenh. 99, $218-223$

Scheit, K.H., Reddy, E.S. \& Bhargava, P.M. (1979) Seminal-plasmin-an antimicrobial protcin from bovine seminal plasma which acts in E. coli by specific inhibition of rRNA synthesis. Nature. Lond. 279, 725-731.

Shu-Dong, T., Phillips, D.M., Halmi, N., Krieger, D. \& Bardin, C.W. (1982) $\beta$-Endorphin is present in the male reproductive tract of five species. Biol. Reprod. 27, 755-764.

Signoret, J.P., du Mesnil du Buisson, F. \& Mauteon, P. (1972) Effect of mating on the onset and duration of ovulation in the sow. J. Reprod. Fert. 31, 327-330.

Skjervold, H. (1975) Comparison of litter size by use of natural and by artificial mating in pigs. Z. Tierzücht. ZïchlBiol. 92, 252-259.

Stanek, R., Veselsky, L., Dostal, J. \& Sedlakova, E. (1985) Effect of boar seminal plasma and seminal vesicle fluid on porcine lymphocytes. Archs Androl. 15, 29-32.

Stites, D.P. \& Erickson, R.P. (1975) Suppressive effect of seminal plasma on lymphocyte activation. Nature. Lond. 253, 727-729.

Stratman, F.W. \& Self, H.L. (1960) Effect of semen volume and number of sperm on fertility and embryo survival in artificially inseminated gilts. J. Anim. Sci. 19, 1081-1088.

Tilton, J.E., Ziecik, A.J., Kirsch, J. \& Weigl, R. (1980) Pattern of $\mathrm{LH}$ release in pigs during estrus. J. Anim. Sci. 51 (Suppl.). 89, abstr.

Tilton, J.E., Foxcroft, G.R., Ziecik, A.J., Coombs, S.L. \& Williams, G.L. (1982) Time of the preovulatory LH surge in the gilt and sow relative to the onset of behavioral estrus. Theriogenology 18, $227-235$. 
Tsafriri, A., Lindner, H.R., Zor, U. \& Lamprecht, S.A. (1972) Physiological role of prostaglandins in the induction of ovulation. Prosiaglandins 2, 1-10.

van de Wiel, D.F.M., Erkens, J., Koops, W., Vos, E. \& van Landeghem, A.A.J. (1981) Periestrous and midluteal time courses of circulating LH, FSH, prolactin, estradiol-17 $\beta$ and progesterone in the domestic pig. Biol. Reprod. 24, 223-233.

Yeselsky, L., Stanek, R. \& Hradecky, J. (198I) Effect of antibodies to boat spermatozoa on fertility in sows and rabbits. Archs Androl. 7; 337-342.

Viring, S. \& Einarsson, S. (1981) Sperm distribution within the genital tract of naturally inseminated gilts. Nord. VetMed. 33, 145-149.
Yamada, Y., Kawai, Y. \& Watanabe, S. (1984) Changes in concentrations of prostaglandins and sex steroids around the time of induced ovulation in prepubertal gilts. Jpn. J. vet. Sci. 46, 677-685.

Zerobin, K. (1968) Untersuchungen über die Uterusmotorik des Schweines. Zentbl. VetMed. A 15, 740-798.

Ziecik, A., Tilton, J.E. \& Williams, G.L. (1981) Effect of mating on the luteinizing hormone surge in the pig. $J$. Anim. Sci. 53, 434-438.

Zöttl, B. (1988) Wirkung von intrauterin verabreichten Östrogenen auf die Prostaglandin- $F_{20}-$ Freisetzung durch das Endometrium und Konsequenzen für die Ovulation des Schweines. Thesis, vet. med. München. 